Digitalizacja archiwalnych numerów czasopisma naukowego Analecta Cracoviensia 1-24 (1969-1992)

i ich publikacja w otwartym dostępie - zadanie finansowane w ramach umowy 672/P-DUN/2017 ze środków

Ministra Nauki i Szkolnictwa Wyższego przeznaczonych na działalność upowszechniającą naukę

KS. TOMASZ JELONEK

\title{
STAROTESTAMENTALNA TEOLOGIA SYJONU
}

$\mathrm{Na}$ zakończenie Jubileuszowego Roku Odkupienia Ojciec Swięty Jan Paweł II wydał List Apostolski Redemptionis anno na temat Jerozolimy jako świętego dziedzictwa wszystkich wierzących w Boga. W Liście tym czytamy słowa: „Jerozolima, zanim jeszcze stała się miastem Jezusa Odkupiciela, była historycznym miejscem biblijnego objawienia Boga, punktem, w którym bardziej niż gdziekolwiek indziej, doszło do nawiązania dialogu pomiędzy Bogiem a ludźmi; była niejako miejscem spotkania ziemi z niebem" ${ }^{1}$. Teologiczne znaczenie Jerozolimy - Syjonu pojawia się już w Starym Testamencie. Celem tego studium jest prześledzenie tego teologicznego obrazu, który przygotowuje nowotestamentalne patrzenie na Syjon jako synonim Kościoła ${ }^{2}$.

W Starym Testamencie Syjon i Jeruzalem (Jerozolima) to nazwy bardzo często występujące zamiennie. Przykładem tego może być paralelny dwuwiersz:

„Chwal, Jerozolimo, Jahwe.

chwal Boga twego, Syjonie" (Ps 147, 2).

$\mathrm{Z}$ tego powodu $\mathrm{w}$ dalszym ciągu nie będziemy rozróżniać tekstów o Syjonie i tekstów o Jerozolimie, jeżeli na ich podstawie da się odtworzyć jeden wspólny obraz starotestamentalnej teologii Syjonu - Jerozolimy. Oprócz bowiem czysto geograficznej i czysto politycznej treści związanej z tymi nazwami, Syjon i Jerozolima najczęściej mają treść teologiczną ${ }^{8}$, która nawiązuje do historycznej, a ujmuje ponadhistoryczną rolę stolicy Dawida i wzgórza Swiątyni.

\section{DZIEJOWE PRZESEANKI TEOLOGII SYJONU}

Już we wczesnych dziejach biblijnych z górą Syjon łączy się opowiadanie o Melchizedeku, królu Salemu (Rdz 14, 18nn) ${ }^{4}$. Według tradycji tą

1 RBL 37(1984), s. 286.

2 Por. T. Jelonek, Obraz Syjonu $w$ Apokalipsie $i w$ Liscie do Hebrajczy$k o ́ w$, „Studia Warmińskie" 12(1975), s. 493.

$\$$ Por. J. S chreiner, Sion-Jerusalem, (Studien zum Alten und Neuen Testament), München 1963, s. 14.

4 Por. tamże, s. 69 n. 
górą jest góra Moria, wzmiankowana w związku z ofiarą, którą Abraham miał złożyć z Izaaka ( $\mathrm{Rdz} 22)^{5}$. Właściwa rola Jerozolimy w historii Izraela i teologii Starego Testamentu rozpoczyna się od zdobycia tego miasta przez Dawida (2 Sm 5, 7). Znaczenie kultyczne i polityczne Jerozolimy już za panowania Dawida podkreślają dwa fakty: sprowadzenie arki do miasta oraz założenie stolicy i dynastii w Jerozolimie. Oba fakty leżą u podstaw teologii Syjonu i dlatego bliżej się nimi zajmiemy.

Histonię sprowadzenia Arki do Jerozolimy poprzedzają jej dzieje opisane w Pierwszej Księdze Samuela (4-6). Arka z pola walki została zabrana przez Filistynów. Kiedy jednak ręka Jahwe zaciążyła nad mieszkańcami Aszdodu (5, 6), twardą się okazała dla ich boga Dagona $(5,7)$, dotknęła wielkim uciskiem miasto Gat $(5,9)$ i siała postrach w innych miastach $(5,11)$, Filistyni postanowili odesłać Arkę. Złożywszy liczne dary odesłano Arkę $(6,8) \mathrm{ku}$ wielkiej radości Izraelitów $(6,13)$. Po powrocie przebywała Arka w domu Abinadaba i stamtąd ją Dawid sprowadiza do siebie (2 Sm 6, 2). Przykry przypadek z Uzzą $(6,6 \mathrm{n})$ powstrzymuje Dawida i przez trzy miesiące zatrzymuje się Arka w domu Obed-Edoma z Gat (6,10n). Kiedy doniesiono Dawidowi, że Jahwe błogosławi Obed-Edomowi z powodu Arki, król przenosi ją do Miasta Dawidowego $(6,12)$. Sprowadzeniu temu towarzyszy wielka uroczystość $(6,13-19)$.

Tak przedstawiają się fakty. Zauważmy, że streszczone tu dzieje Arki nasuwają bardzo znamienną myśl. Arka przymierza jako materialny znak obecności Jahwe uwypukla zarazem ambiwalencję tej obecności. Jest ona pełna grozy i śmiercionośna dla wrogów narodu wybranego i tych, którzy zbliżają się do Arki bez należytej powściągliwości (por. Lb 4, 15 - zakaz dotykania Arki przez niosących ją). Z drugiej zaś strony obecność Jahwe poprzez Arkę obdarza radością i błogosławieństwem. Od sprowadzenia Arki na Syjon ta groźna a równocześnie obdarzająca błogosławieństwem obecność Jahwe zamieszka na Syjonie. Tu tkwią korzenie myśli teologicznej, która z Syjonem wiązać będzie sąd Boży. Do tej myśli będziemy musieli powracać w miarę formowania się pełnej teologii Syjonu.

Drugim istotnym dla znaczenia Syjonu faktem z czasów Dawida jest założenie dynastii w Jerozolimie. Dawid zdobył Syjon (2 Sm 5, 7), po zbudowaniu pałacu uznał on, że „Jahwe potwierdził go królem nad Izraelem i że jego władzę królewską wywyższył ze względu na lưd swój - Izraela" (2 Sm 5, 12). To stwierdzenie podkreśla specyfikę władzy królewskiej w Izraelu. Pochodzi ona od Jahwe, który jest właściwym władcą Izraela i ustanowiona jest ze względu na lud Boży. Król nie jest więc niezależnym autokratą, lecz przewodnikiem ludu należącego do Jahwe. To specyficzne znaczenie monarchii w Izraelu trzeba mieć na uwa-

5 Por. H. W. Montefiore, A commentary on the Epistle to the Hebrews, (Black's New Testament Commentaries), London² 1969, s. 230. 
dze, gdy przechodzimy do zagadnienia dynastii założonej przez Dawida. Pismo święte stara się przedstawić go jako wzór króla w Izraelu i jako typ Mesjasza-Króla. Jemu zostały dane obietnice (2 Sm 7), a jego królestwo ma trwać na wieki. Historycznie biorąc ani obietnice, ani wzorzec króla nie zostały zrealizowane przez królów pochodzących od Dawida i panujących aż do niewoli babilońskiej. Teokratyczne i idealne królestwo Dawida zrealizuje dopiero - ze swoistą transpozycją - Nowe Przymierze. Idea Królestwa Dawidowego zrosła się jednak w Starym Testamencie z Syjonem jako nieodłączny element jego teologii, teologii Stolicy Izraela i Miasta Swiętego. Z tego też powodu zatrzymamy się nad głębszą analizą idei tronu Dawida, który ma trwać na wieki (2 Sm 7, 13).

W nawiązaniu do proroctwa Natana (2 Sm 7, 3-16) idea królestwa Dawidowego powraca często w Psalmach. Samą obietnicę wyrażoną przez Natana powtarzają Psalm 89, 4n. 27-38 oraz Psalm 132, 11n. Podkreślona jest $\mathrm{w}$ tych Psalmach konieczność wierności króla przymierzu zawartemu z Dawidem. Król został ustanowiony na Syjonie, świętej górze Jahwe (Ps 2, 6). Syjon jest miejscem wybranym przez Jahwe na szczególną siedzibę (Ps 132, 13) i tam Jahwe wzbudzi moc Dawida i światło dla swego pomazańca (Ps 132, 17), z Syjonu Jahwe rozciągnie jego potęgę i panowanie (Ps 110, 2), z Syjonu ma go wspierać (Ps 20, 3). Wzorowy król ma kroczyć drogą nieskalaną według niewinności swego serca (Ps 101,2), a z miasta Jahwe (Jerozolimy) ma wygubić wszystkich złoczyńców (Ps $101,8)$.

Zbierając naukę Psalmów o królu z domu Dawida trzeba uwypuklić następujące jego rysy ${ }^{\circ}$ :

- Królestwo ugruntowane jest na Syjonie, w miejscu wybranym przez Jahwe.

- Król - pomazaniec jest umiłowanym synem Boga. Psalm 89 nazywa go nawet pierworodnym (Ps 89, 28).

- Król jest zastępcą Jahwe, ma go słuchać i dbać o świętość Miasta Bożego.

- Z Syjonu płynie dla króla pomoc i siła.

Królestwo Dawidowe jest zatem królestwem teokratycznym, jest znakiem królowania Jahwe. Kiedy więc ten znak przez ludzką nieudolność przestanie spełniać swą rolę, kiedy później zawierucha dziejów zmiecie go $\mathrm{z}$ areny politycznej, w oczekiwaniu Izraela pozostanie świadomość nieodwołalnej obietnicy Jahwe. Syjon jako siedziba królestwa stanie się symbolem eschatologicznego królowania Jahwe. Tak zatem założenie przez Dawida stolicy i dynastii na Syjonie leży u podstaw jego teologii.

Do faktów, które związane są z panowaniem Dawida, a które leżą u podstaw tworzącej się teologii Syjonu trzeba dodać budowę świątyni

${ }^{6}$ Por. J. Schreiner, jw. (przyp. 3), s. 102-136.

30 - Analecta Cracoviensia 
przeprowadzoną za następcy Dawida, Salomona. Jest ona dalszym ciągiem dziejów Arki, która w świątyni ostatecznie spoczęła, jest równocześnie pełniejszym wyrazem obecności Jahwe na Syjonie. W teologicznym spojrzeniu, jakiego dostarczają nam Psalmy, przybycie Jahwe na Syjon (przez przybycie Arki) i Jego na nim zamieszkanie (w świątyni) zlewa się w jeden wspólny obraz.

W opisie budowy świątyni podkreślone jest założenie jej fundamentów (1 Krl 5, 31; 6, 37). Użyte tu słowo hebrajskie jest terminem, którego używa Stary Testament na oznaczenie stwórczej działalności Jahwe zakładającego fundamenty ziemi i nieba (Am 9, 6; Iz 48, 13; 51, 13. 16; Za 12, 1; Ps 24, 2). Ludzka działalność przy budowie świątyni jest dla teologii Syjonu widzialnym znakiem działania Bożego, który wybrał ,,górę Syjon, którą umiłował i wzniósł swoją świątynię jak wysokie niebo, jak ziemię, którą ugruntował na wieki" (Ps 78, 68n). Izajasz tę teologiczną myśl streści krótko: „Jahwe założył Syjon” (14,32). Fundament świątyni wykonany został przez rzemieślników Salomona z wyborowych kamieni

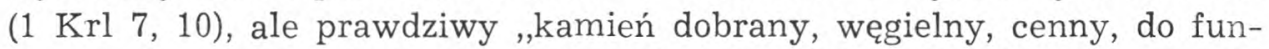

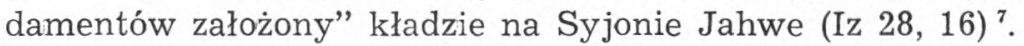

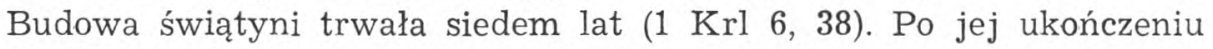
nastąpiło uroczyste przeniesienie Arki do świątyni i jej poświęcenie. Kiedy „chwała Jahwe napełniła dom Jahwe” $(8,11)$, Salomon przemówił do Boga: „Zbudowałem $\mathrm{Ci}$ dom na mieszkanie, miejsce przebywania Twego na wieki" $(8,13)$. Tak więc spełniło się to, co tyle razy zapowiada Księga Powtórzonego Prawa, że Jahwe wybierze sobie miejsce, będące jedynym ośrodkiem kultu i miejscem zamieszkania Jego imienia (Pwt 12, 5. 11. 14. 18. $21.26 ; 14,23$. $25 ; 15,20 ; 16,2$. 6. 7. $11.15 .16 ; 17,8.10 ; 26,2)^{8}$. To zapowiadane miejsce obejmuje Bóg w posiadanie. Psalmy w sposób poetycki odmalowują fakty opisane w Pierwszej Księdze Królewskiej jako uroczyste wejście Jahwe na górę Syjon i do świątyni (Ps 24; 68; 132), podkreślając szczególne wybranie Syjonu (Ps 78, 67; 132, 13). To wybrane miejsce miało być również miejscem zgromadzenia wybranego ludu Izraela, któremu w tym miejscu będzie czytane Prawo (Pwt 31, 11). Zgromadzenie ludu widzimy w czasie poświęcenia świątyni (1 Krl 8, 14). I chociaż wypadki historyczne oddzieliły większość pokoleń izraelskich od bezpośredniego kontaktu z Jerozolimą, Syjon w świadmości Izraela pozostanie zawsze związany $\mathrm{z}$ dwunastoma pokoleniami ${ }^{9}$. Chciaż nie będzie się przy nim zbierał Izrael historyczny, będzie to miejsce zebrania Reszty Izraela ${ }^{10}$. Bóg bowiem mieszka na Syjonie pośród swego ludu.

7 Jest to tekst, do którego Nowy Testament kilkakrotnie nawiązuje, por. Mt 16,$18 ; 21,42 ;$ Ef 2,$20 ; 1 \mathrm{P} 2,6 \mathrm{n}$.

8 Por. J. Schreiner, jw. (przyp. 3), s. 51.

9 Por. tamże, s. 190.

10 Por. J.-L. D'A ra go n, The Apocalypse, JBC, t. 2, s. 484. 
Rozważane powyżej fakty historyczne, jak już śledziliśmy, są dziejowym fundamentem, na którym opiera się teologia Syjonu jako stolicy teokracji, miejsca kultu i przebywania Jahwe. Teologia ta stopniowo przesuwa akcenty z rzeczywistości widzialnej na rzeczywistość niewidzialną. Przykładem tego może służyć omawiana już sprawa fundamentu świątyni. Wychodząc od faktu stawiania fundamentów, przez użycie terminu dotyczącego Bożego działania stwórczego, teologia dochodzi do stwierdzenia Bożej inicjatywy w budowaniu Syjonu, która należy już do sfery pozazmysłowej. Tak więc na podstawie faktów, o których była mowa, Stary Testament wprowadza zrąb teologii Syjonu. Syjon jest miejscem obecności Jahwe, który wybrał sobie Syjon na mieszkanie. W swym mieście Jahwe jest nieograniczonym Panem. Ze swego świętego miejsca na Syjonie jest Jahwe Panem nad domem królewskim i prawdziwym królem narodu wybranego ${ }^{11}$. Teologia Syjonu przedstawiona tu zarysowo będzie się rozwijać w późniejszych księgach Starego Testamentu.

\section{SYJON W KSIĘDZE PSALMOW}

Już poprzednio obserwując jak teologia Syjonu rozwija się na pod-stawie faktów dziejowych, sięgaliśmy do Księgi Psalmów. Ona bowiem na fakty opisywane w księgach historycznych patrzy nie tylko w sposób poetycki, ale również teologicznie. To jednak, co zostało już powiedziane o Syjonie w Księdze Psalmów, nie wyczerpuje bogatej wizji Syjonu, jaką Psalmista rysuje przed naszymi oczyma. Z tej bogatej treści chcemy teraz skorzystać w celu odtworzenia możliwie pełnej teologii Syjonu w Starym Testamencie ${ }^{12}$. Księga Psalmów, a więc księga religijnych pieśni, będąca modlitewnikiem narodu wybranego i młodego chrześcijaństwa, musiała swoją teologią wywierać duży wpływ na nowotestamentalne pojęcie Syjonu. Z tego względu obrazowi Syjonu w Księdze Psalmów poświęcimy specjalne rozważanie.

Syjon $\mathrm{w}$ Psalmach to przede wszystkim góra Jahwe $(2,6 ; 15,1$; $24,3 ; 43,3 ; 48,2 ; 78,68)$, miasto Jahwe $(24,3 ; 43,3 ; 48,3)$, Jego święte miejsce $(15,1 ; 76,3)$, które obrał sobie na siedzibę $(9,12 ; 68,17 ; 74,2$; $78,68 ; 132,13 ; 135,21)$. Wybór Jahwe daje Syjonowi trwałość na wieki. Na swojej górze Bóg będzie mieszkał na zawsze $(68,17)$, Syjon będzie spoczynkiem Jahwe na wieki $(132,14)$ i Jego także na wieki królowaniem $(146,10)$. Dlatego Bóg na górze Syjon wzniósł swoją świątynię tak ugruntowaną na wieki jak niebo i ziemia $(78,69)$, a góra Syjon, która się nie porusza, ale trwa na wieki jest przykładem mocnego zakorzenienia (125,

11 Por. J. Schreiner, jw. (przyp. 3), s. 100n.

12 Por. H.-J. Kraus, Psalmen, Berlin ${ }^{4} 1972$, s. LXIV-LXXIII. 
1). Arka przymierza, która ostatecznie została umieszczona na Syjonie, oraz kult liturgiczny ustanowiony przez Mojżesza, a sprawowany legalnie jedynie w świątyni, są łącznikami pomiędzy Synajem a Syjonem. Psalm 68 opisuje przejście Jahwe z Synaju na Syjon. Na Bliskim Wschodzie kult wiązał się $\mathrm{z}$ górami jako tronami Boga ${ }^{13}$. Razem ze swym ludem Jahwe wędruje przez pustynię (8-11), towarzyszy mu swą pomocą w zdobyciu ziemi obiecanej (12-15). Jest to pochód Jahwe: „Rydwanów Bożych jest tysiące tysięcy; to Pan do świątyni przybywa z Synaju" (18). Góra, którą wybrał Jahwe w porównaniu z innymi jest mała, dlatego wysokie i urwiste góry Baszanu z zazdrością na nią patrzą, Syjon przewyższa jednak inne góry swą świetnością. Z niego bowiem, będącego koroną piękności, zajaśniał Bóg w swej chwale, która zamieszkała w świątyni $(50,2)$. Księga Psalmów zawiera przeto specjalne pieśni o Syjonie (Ps 46, Ps 48, Ps 76, Ps 84 , Ps 87 , Ps 122), w których dominuje wspólna myśl. Jest to miłość do Syjonu i wiara w obecność Boga pośród swego ludu ${ }^{14}$.

Syjon jest siedzibą Jahwe, który mieszka wśród swego ludu $(46,12)$. Błogosławieni, którzy mieszkają w domu Pana (84, 5), tam Jahwe gromadzi rozproszonych z Izraela, sam ich leczy i przewiązuje ich rany (147, 2n), poucza o swoich wyrokach $(147,20)$. Psalmy 15 i 24 mówią o tym, kto będzie przebywał w przybytku Boga i na Jego świętej górze $(15,1)$, kto wstąpi na górę Jahwe i stanie na świętym miejscu $(24,3)$. Psalmy tak określają człowieka przebywającego na Syjonie:

Człowiek o rękach nieskalanych i o czystym sercu, który nie skłonił swej duszy ku marnościom

i nie przysięgał fałszywie $(24,4)$

Ten, który postępuje bez skazy, działa sprawiedliwie, a mówi prawdę w swoim sercu

i nie rzuca oszczerstw swym językiem;

ten, który nie czyni bliźniemu nic złego

i nie ubliża swemu sąsiadowi;

kto złoczyńcę uważa za godnego wzgardy,

a szanuje tego, kto się boi Jahwe;

ten, kto dotrzyma, choć przysiągł ze swoim uszczerbkiem;

ten, kto nie daje swoich pieniędzy na lichwę

i nie da się przekupić przeciw niewinnemu $(15,2-5)$.

W omawianym już Psalmie 68 znajdujemy bardzo istotną dla nas myśl, która nawiązuje do wspomnianej w poprzednim podrozdziale ambis. 403 .

18 Por. C. Spicq, L'Épître aux Hébreux, (Etudes Bibliques), Paris² 1952, t. 2,

${ }_{14}$ Por. L. Sabourin, The Psalms, New York 1969, t. 1, s. 230. 
walencji Bożej obecności. Znów najlepiej będzie ideę biblijną przedstawić w całej krasie poetyckiej przez zacytowanie przekładu:
Bóg wstaje a rozpraszają się Jego wrogowie
i pierzchają przed Jego obliczem ci, którzy Go nienawidzą.
Rozwiewają się, jak dym się rozwiewa,
jakk woosk się rozpływa przy ogniu,
tak giną przed Bogiem grzesznicy.
A sprawiedliwi się cieszą i weselą
przed Bogiem i radością się rozkoszują. $(68,2 \mathrm{nn})$.

Przepiękny w swej ekspresji tekst wyraża teologię sądu Bożego, tyle razy wspominanego i zapowiadanego w Starym Testamencie, a w szczególności także w Księdze Psalmów. Teologicznym ujęciem sądu Bożego zajmiemy się szerzej $\mathrm{w}$ następnym podrozdziale, gdy omawiając prorocką wizję Syjonu będziemy co krok znajdować teksty mówiące o sądzie. W tej chwili dla nas najważniejszym jest fakt, że sąd Boży pojawia się w Psalmie opisującym ingres Boga na Syjon. Pan zamieszkujący na Syjonie, to Bóg groźny dla swych wrogów i źródło radości dla sprawiedliwych. Jahwe jest królem w zgromadzeniu świętych na Syjonie $(149,2)$. Mieszkańcy Syjonu, jego synowie to Izrael, jak świadczy o tym paralelizm wspomnianego ostatnio wiersza. Od tych mieszkańców wymagane są zacytowane wyżej przymioty moralne. Liczna grupa Psalmów sławi Jahwe jako Króla (Ps 47, Ps 93, Ps 96, Ps 97, Ps 149). On z Syjonu otacza opieką swój lud $(125,2)$, z Syjonu wysyła swą wspierającą siłę $(20,3 ; 48,4$; $110,2)$, Syjon to miejsce, z którego wychodzi zbawienie $(50,23)$. Tu jak do centrum schodzi się Izrael (Ps 84, Ps 122), do Syjonu przyjdą wszystkie ludy $(86,9 ; 87,6)$. Syjon to miejsce zgromadzenia. Przy Syjonie gromadzą się z radością $(149,2)$ sprawiedliwi, umiłowani Jahwe, którzy przez ofiarę zawarli z nim przymierze i postępują bez skazy (Ps 50), radują się oni z wyroków Pana $(97,8)$, a wyroki te są sądem nad niezbożnymi. Syjon to tron Boga - Sędziego. Bóg, który przybył na Syjon ,nie milczy, przed Nim ogień trawiący, wokół Niego szaleje nawałnica” $(50,3)$.

Izrael historyczny nie okazał się tym idealnym Izraelem godnym wstąpienia na górę Pańską. I przeciw niemu obrócił się gniew Jahwe. Nad gruzami świątyni modli się Psalmista: „Pomnij na Twą społeczność, którą dawno nabyłeś, na pokolenie, które wziąłeś w posiadanie, na górę Syjon, gdzie założyłeś sobie siedzibę" $(74,2)$. Pośród powszechnego zepsucia (Ps 14) zbawienie Izraela ma przyjść z Syjonu, gdy Pan odmieni los swego narodu $(14,7)$. Toteż w Psalmie 43 Psalmista prosi o powrót na świętą górę Jahwe $(43,3)$, wierząc, że przystąpi do Boga, który jest' jego weselem i radością $(43,3)$. Przecież z Syjonem wiążą się obietnice Jahwe dane Dawidowi, od których Bóg nie odstąpi $(78,70 ; 89,27 n ; 132$, 11). Tragiczne losy Izraela kierują wzrok ku przyszłej realizacji obietnic. 
Zbawienie przychodzące z Syjonu (14, 7; 50, 23) nastąpi w czasach eschatologicznych, a królestwo Jahwe na Syjonie $(146,10 ; 149,2)$ będzie królestwem eschatologicznym ${ }^{15}$. Dlatego w Ps 2, 6 możemy widzieć sens mesjański ${ }^{16}$. Syjon jest górą Mesjasza - Króla, który na Syjonie zostanie ustanowiony.

Staraliśmy się pozbierać różne elementy, które w Księdze Psalmów składają się na wizję Syjonu ${ }^{17}$. Wiele $\mathrm{z}$ tych elementów odnajdziemy $w$ księgach prorockich. Syjon to królestwo Jahwe, którego historyczna świątynia jest tylko znakiem i zadatkiem. Dlatego ,pieśni stopni” (Ps 120-Ps 134) tchnące wielką radością z faktu zdążania do Jerozolimy i pragnieniem znalezienia się w jej murach (Ps 122) są pieśniami ludu Bożego pielgrzymującego ku ostatecznemu zakrólowaniu Boga.

\section{SYJON W WIZJI PROROKÓW}

Na postawiony $\mathrm{w}$ tytule temat można by napisać monografię. Uwagi tu poczynione nie mogą więc sobie rościć pretensji do wyczerpania tematu. Nie o to chodzi. Z całego możliwego do wykorzystania materiału trzeba wybrać tylko przykładowe i najbardziej charakterystyczne miejsca. Pism proroków nie można oderwać od nich samych i od czasów w jakich żyli. Wychodzą oni bowiem od konkretnych sytuacji życiowych, choć widzą także rzeczywistość w perspektywie prorockiej, nakładającej obrazy rzeczy przyszłych na obrazy bliższych — istniejących lub nadchodzących faktów. W miarę postępu czasu i dokonywania się faktów historycznych, obraz coraz bardziej zwraca się ku eschatologicznej przyszłości. Ten rozwój myśli proroków widać również w ich wizji Syjonu. Fundamentalną ideą $\mathrm{w}$ oczekiwaniu przyszłości jest zawsze zakrólowanie Jahwe i rozrachunek z wrogami ${ }^{18}$. Oba aspekty wiążą się z Syjonem. Wydarzenia historyczne oddalają zakrólowanie Jahwe i pogrom wrogów. Prorocy zapowiadają i są świadkami upadku Jerozolimy i zwycięstw odnoszonych przez wrogów nad Izraelem, który jest niewierny. Teokracja Dawidowa i świątynia na Syjonie legną w gruzach. Podtrzymując ducha narodu, u proroków coraz bardziej dochodzi do głosu mesjanizm, przez który można rozumieć wypowiedzi i oczekiwania mające na względzie nie tyle osobę Mesjasza, co w ogóle czasy przyszłe ${ }^{19}$. Ta idea także wiąże się z Syjonem.

15 Por. G. Fohrer, Zion-Jerusalem im AT, ThWNT, t. 7, s. 312.

${ }_{16}$ C. Spicq, L'Épitre aux Hébreux, t. 2, s. 405; J.-L. D'A ragon, The Apocalypse, jw. t. 2, s. 484.

17 Por. D. C. Szumilo, Nauka o Syjonie $w$ Księdze Psalmów, Kraków 1982 (maszynopis), passim.

18 Por. R. Schnackenburg, Gottes Herrschaft und Reich, Freiburg im $\mathrm{B}^{4} 1965$, s. 14 .

19 Por. J. Homerski, Królestwo mesjańskie $w$ nauczaniu proroków, RTK, 11, 1 (1964), s. 39. 
Wspomniane powiązania teologii Syjonu z podstawowymi ideami nauczania prorockiego postaramy się wykazać przechodząc kolejno pisma proroków według chronologii ich życia. Pozwoli nam to ująć różne aspekty teologii Syjonu i jej rozwój.

Prorok Amos zapowiadając sąd Jahwe nad narodami i nad Izraelem mówi, że Jahwe zagrzmi z Syjonu i wyda swój głos z Jeruzalem $(1,2)$. Tron sądzącego i karzącego Boga znajduje się na Syjonie. Jest to szczególnie ważne stwierdzenie $\mathrm{w}$ ustach proroka działającego w królestwie izraelskim ${ }^{20}$. Syjon mimo rozdziału królestw dla prawdziwego Izraelity pozostaje stolicą Jahwe ze względu na świątynię. Nie obca jest też prorokowi myśl o królestwie Dawida, które zostanie odbudowane jak za dawnych dni $(9,11)$, wtedy przesiana zostanie Reszta z domu Jakuba $(9,8 n)$. Zważywszy, że stolica Dawida związana jest z Syjonem, możemy stwierdzić, że w czasach rozkładu jedności państwowej i upadku moralnego prorok nawiązuje do historycznych podstaw teologii Syjonu, nadając jednak zapowiedzi odrodzenia królestwa charakter mesjański. Swiadczą o tym zwroty „w owym dniu" $(9,11)$, „oto nadchodzą dni” $(9,13)$, zapowiedź wiecznego trwania $(9,15)$ i rozszerzenie królestwa na wszystkie narody $(9,12)^{21}$.

Syjon u proroka Izajasza odgrywa szczególną rolę i jest wymieniany bardzo często. J. Schreiner zauważa, że dla Izajasza Syjon jest miejscem przebywania Jahwe. Odróżnia on Syjon i stolicę królestwa judzkiego, której nie nazywa Syjonem ${ }^{22}$. Nazwę Jerozolimy stosuje prorok na oznaczenie miasta grzechu ściągającego sąd Boży $(3,8.16 ; 10,11 ; 22,1-14$; $28,14 n)^{28}$, gdzie indziej mówi o Jerozolimie jako o synonimie Syjonu $(2,3 ; 4,3)$. Ten ostatni jednak termin nabiera już czysto teologicznego znaczenia. Izajasz nawiązuje do teologicznej tradycji, widzącej w Syjonie miejsce zamieszkania Jahwe $(8,18)$ i ośrodek Jego królowania (24, 23). Równocześnie prorok nawiązuje do faktów historycznych, które za jego życia się rozgrywają ${ }^{24}$. Widzi on zepsucie i odstępstwo od Boga, wciskające się nawet na tron potomków Dawida, głosi więc nadchodzący sąd Jahwe. W tym kontekście trzeba widzieć wypowiedzi o Syjonie. Sąd Boży dotyczy wrogich narodów, ale także sąd ten grozi wiarołomnemu Izraelowi i dokonuje się faktycznie w dziejowych wypadkach. Po wielkiej katastrofie kary Bożej pozostanie Reszta, z niej rekrutować się będzie społeczność mesjańskiego królestwa ${ }^{25}$, którego centrum będzie Syjon.

${ }^{20}$ Por. E. Z a wiszewski, Księga Amosa, [w:] Księgi proroków mniejszych, Poznań 1968, t. 1 , s. 187.

21 Por. Tamże, s. 256.

22 Por. J. S chreiner, jw. (przyp. 3), s. 269.

28 Por. G. Fohrer, jw. (przyp. 15), s. 309.

24 Por. G. vom Rad, Theologie des AT, Berlin² 1969, t. 2, s. 162-175.

25 Por. J. Homerski, jw. (przyp. 19), s. 47. 
Na Judę spadnie kara, gdyż opuścili Jahwe (1, 2-7). Jahwe jednak zostawi Resztę $(1,9)$. Kiedy buntownicy i grzesznicy będą starci, a odstępujący od Jahwe wyginą $(1,28)$, Syjon okupi się poszanowaniem Prawa, a jego nawróceni sprawiedliwością $(1,27)$. Wśród różnych zapowiedzi sądu pojawiają się poematy ukazujące mesjańską wizję Syjonu (2, 2-5; 4, 2n) ${ }^{26}$, odnowienie Syjonu malują także wiersze 4, 4nn. Brud Córy Syjonu - a więc Jerozolimy - zostanie oczyszczony tchnieniem sądu $(4,4)$, natomiast $z$ Syjonu wyjdzie Prawo i słowo Jahwe $(2,3)$. Sam Syjon stanie mocno na wierzchołku gór $(2,2)$, na nim spocznie Jahwe $(4,5)$, a przy nim zgromadzi się Reszta ocalałych z Izraela $(4,2)$. Ku Syjonowi podążą wszystkie narody, $(2,2)$, aby nauczyć się dróg Bożych $(2,3)$. Kto pozostanie na Syjonie będzie nazwany świętym i wpisany do księgi życia w Jeruzalem (4, 3), na zgromadzonych zejdzie Jahwe (4, 5), a Jego Chwała będzie ich osłoną i schronieniem $(4,5 n)$.

Przedstawiona tu Izajaszowa mesjańska wizja Syjonu ubogaca się dalszymi elementami rozsianymi w różnych miejscach proroctwa. Są to jasne, rozświetlone mesjańską aureolą momenty, świadczące, że dla proroka Syjon jest niezwyciężonym palladium narodu $(28,16)$ a Jerozolima - mimo upadku - ośrodkiem przyszłego panowania Jahwe ${ }^{27}$. Oto wspomniane elementy: Reszta powróci do Boga i oprze się na Jahwe (10, 20n), Bóg nazwie ich swoim ludem (10, 24), wykupi ich $(11,11)$ i sprowadzi $(11,16)$. Nie będą oni czynić zła, a napełni ich znajomość Jahwe $(11,9)$. Syjon będzie schronieniem $(14,32)$ i bezpieczną siedzibą $(33,20)$, na tej bowiem górze Jahwe zakróluje $(24,23)$ i na niej zstąpi do boju $(31,4)$. Dla wszystkich ludów przygotuje ucztę $(25,6)$ i zniszczy śmierć $(25,8)$. Wszystkie elementy zebrane razem tworzą bogatą wizję Syjonu. Naprawdę na nim Jahwe kładzie cenny, dobrany kamień węgielny nowej Jerozolimy $(28,16)$.

Przejdziemy do wizji Micheasza współczesnego Izajaszowi. Nie różni się ona od poprzedniej. I tu występuje kontekst zapowiadanego sądu, z pogromu ocaleje Reszta $(2,12 ; 5,6 \mathrm{n})$, która zebrana na górze Syjon będzie królestwem Jahwe na zawsze $(4,7)$. Micheasz w 4, 1-5 przytacza opis panowania Jahwe na Syjonie zamieszczony u Izajasza w 2, 2-5. Prawdopodobnie obaj zależą od wspólnego fragmentu starszej literatury ${ }^{28}$.

Prorok Jeremiasz, to prorok, który zapowiada i przeżywa upadek Jerozolimy i koniec królestwa judzkiego. Na politycznym tronie nie zasiada już żaden potomek Dawida, lud został rozproszony i wygnany. s. 295 .

${ }_{26}$ Por. J. Steinmann, Le Prophète Isaïe, (Lectio Divina 5), Paris ${ }^{2}$ 1955,

${ }_{27}$ Por. J. Homerski, jw. (przyp. 19), s. 47.

28 Por. P. Szefler, Księga Micheasza, [w:] Księgi proroków mniejszych, praca zbiorowa, Poznań 1968, t. 1, s. 391. 
Dziejowe i doczesne przesłanki teologii Syjonu rozsypały się w proch. Syjon i Jerozolima pokazują się w oczekiwaniu odnowy. Bóg bowiem zbierze swą Resztę $(23,3)$, zaprowadzi na Syjon (3, 14), wzbudzi Dawidowi Odrośl sprawiedliwą (23, 5). Prorok oczyma swymi widzi karę Bożą. Syjon nazywa ,odrzuconą, o którą się nie ma kto zatroszczyć” $(30,17)$. Tenże sam Syjon w wizji proroczej jest nadal siedzibą Jahwe $(31,6)$. Sąd karzącego Boga wykazuje obserwowaną już poprzednio ambiwalencję widoczną w rozdzieleniu losu ludu Bożego i ludzi niegodziwych. Swiadczą o tym dwa następujące po sobie wiersze: „Wy będziecie moim narodem, a Ja będę waszym Bogiem. Oto nawałnica Jahwe, gniew powstaje, burza szalejąca na głowę niegodziwych" (30, 22n). Palący gniew Jahwe dokonuje zamysłów swego serca $(30,24)$. Plan Boga karającego może być niezrozumiały i budzić sprzeciw, ale prorok uspokaja znamiennymi słowami: „Przy końcu dni to zrozumiecie” $(30,24)$. Plany Boże staną się jasne, a Jego miłość $(31,3)$ się objawi. Wtedy Jahwe będzie Bogiem dla całego Izraela $(31,1)$ i wybawi Resztę $(31,7)$, jest On bowiem Ojcem dla Izraela, który jest jego pierworodnym (31, 9). Rozproszenie się skończy, naród powróci $(31,8)$. Celem pielgrzymki powracających z niewoli jest wzgórze Syjon, z którego popłynie błogosławieństwo Jahwe (31, 12) ${ }^{29}$. To błogosławieństwo przedstawione jest jako pomyślność materialna: „rozradują się błogosławieństwem Jahwe: zbożem, winem, oliwą, owcami i wołami" $(31,12)$. Wymienione dobra były materią ofiar. Prorok dodaje, że radość zebranych objawi się tańcem $(31,13)$, a kapłani będą mieli obfitość tłuszczu $(31,14)$. Cały ten obraz podkreśla kultyczny charakter zgromadzenia powracających na Syjon ${ }^{80}$.

Przedstawiona tu wizja Syjonu stanowi kontekst zapowiedzi Nowego Przymierza (31, 31-34). To połączenie jest bardzo ważne i ono świadczy o tym, że w prorockiej wizji odbudowana Jerozolima $(31,38 ; 33,4 \mathrm{nn})$ to Jerozolima Nowego Przymierza $(32,37-41)$. ,W tamtych czasach Jerozolima będzie się nazywała tronem Jahwe. Zgromadzą się w niej wszystkie narody w imię Jahwe i nie będą już postępowały według zatwardziałości swych przewrotnych serc" $(3,17)$. Warunkiem należenia do nowej społeczności nowej Jerozolimy jest szczerość i prostolinijność postępowania. Dla zatwardziałych, przewrotnych i upartych nie będzie tam miejsca. Wtedy też prerogatywy Arki Przymierza przejdą na całe święte miasto, stolicę Jahwe i miejsce Jego obecności [3, 16]. Taką wizją Syjonu i przyszłej Jerozolimy pocieszał Jeremiasz tych, którzy przeżywali klęskę miasta i państwowości. Syjon stanie się zapowiadanym miejscem powrotu u proroków okresu wygnania.

29 Por. L. Stachowiak, Księga Jeremiasza, Poznań 1967, s. 345.

30 Por. tamże. 
U Ezechiela Izrael nie ma już treści politycznej, ale religijną ${ }^{\text {s1 }}$, jest to Reszta, którą Bóg zachowa i sprowadzi (34, 13-16), ustanawiając nad nią pasterza z rodu Dawida $(34,23)$. Prorok zapowiada też nową świątynię (40-47), do której powróci Chwała Jahwe (43, 1-12). Prorocza więc wizja nowych czasów nawiązuje do teokracji Dawidowej i świątyni Jahwe, obu aspektów budujących teologię Syjonu. Oba są u Ezechiela pozahistoryczne.

Syjon i Jerozolima odgrywają wielką rolę w proroctwie Deutero-Izajasza. Wyzwolenie z niewoli przedstawia on jako nowe Wyjście, nawiązując celowo do typu ostatecznego wyzwolenia jakim było wyjście z Egiptu. Nowe wyjście będzie wyjściem cudownym (Iz 41, 17-20;43, 16-21) i tryumfalnym $(52,11 \mathrm{n})$, przewodnikiem będzie Jahwe $(48,17)$, przed Nim należy wyrównać drogę $(40,3 \mathrm{n})$. Wieść o powrocie Boga napełnia Syjon (40, 9), Jahwe przychodzi z moca i władzą, przed nim idzie nagroda i zapłata $(40,10)$. Zbawienie Izraela będzie wieczne i nigdy już Izrael nie zazna zawstydzenia $(45,17)$, zbawienie to złożone będzie w Syjonie $(46,13)$, więc odkupieni przybędą na Syjon z radosnym śpiewaniem $(51,11)$, podczas gdy ramię Jahwe będzie sądzić ludy $(51,5)$. Jahwe rozciągnął niebo, założył ziemię i Syjonowi mówi: „Tyś moim ludem”. Toteż Syjon ma się przebudzić, przyodziać swoją moc $(52,1)$, w nim będzie królować Bóg jego $(52,7)$. Gdy więc wypadki historyczne wykazały, że polityczne królestwo założone przez Dawida się nie udało, Syjon staje się stolicą mesjańskiego królestwa Jahwe. Poemat o odrodzeniu Jerozolimy (52, 1n. 7-12) poprzedza czwartą pieśń o Słudze Jahwe $(52,13-53,12)^{82}$, po której opisana jest chwalebna przyszłość Jerozolimy ${ }^{83}$. Tajemnicza postać tego, który dźwiga cierpienia innych $(53,4)$, który za grzechy innych jest przebity $(53,5)$ i który usprawiedliwia wielu $(53,11)$, w ten sposób znalazła się w kontekście przyszłej świetności Syjonu. Nie rozstrzygając, czy Redaktor Księgi uczynił to celowo czy przypadkowo, możemy zauważyć, że dla czytelnika Księgi Izajasza, a zwłaszcza dla odczytujących ją autorów Nowego Testamentu, wspomniany kontekst i plynące $z$ niego powiązania nie mogły być obce. Nowa Jerozolima będzie płodna w potomstwo $(54,1-3)$, otoczy ją miłość Jahwe $(54,4-9)$, który zawrze z ludem wieczyste przymierze $(55,3)$.

Kiedy zmieniona sytuacja polityczna pozwoliła na powrót Izraelitów do ojczyzny i odbudowę świątyni, okazało się, że rzeczywistość blado wypada wobec prorockich zapowiedzi. Swiątynia nie dorównywała nawet tej, która była zburzona (Ag 2,3), nie mówiąc o zapowiadanej świetności.

${ }^{31}$ Por. J. Homerski, jw. (przyp. 19), s. 49.

${ }^{32}$ Por. J. Steinmann, Le Livre de la consolation (Lectio Divina 28), Paris 1960 , s. 168.

33 Por. tamże, s. $177-181$. 
Prorocy musieli tłumaczyć ludowi, że przepowiednie zrealizują się nie teraz, ale w mesjańskiej przyszłości (Ag 2, 9). Wprawdzie świątynia na Syjonie po niewoli stała się jedynym i absolutnym punktem centralnym religii judaizmu ${ }^{34}$, Syjon jednak stawał się miejscem oczekiwanego zbawienia eschatologicznego ${ }^{35}$. Do świątyni przyjdzie Pan, którego Izrael oczekuje (Ml 3, 1). Oczekiwanie to podlega ewolucji, w obrazie Syjonu pojawiają się nowe elementy ${ }^{36}$. Rozwój wizji Syjonu prześledzimy posługując się dotychczasową metodą kolejnego omawiania wkładu poszczególnych proroków.

U Zachariasza ${ }^{37}$, który dużo mówi o Syjonie i Jerozolimie, nie spotykamy właściwie nowych idei. Prorok podkreśla zazdrosną miłość Jahwe do Syjonu (1, 14; 8, 2). Jahwe znów sobie wybiera Syjon i Jerozolimę (1, $17 ; 2,16 ; 8,3)$. Tu sprowadzi Resztę, tu liczne ludy będą ściągać (2, 15; 8, 20nn). Raz jeszcze wraca powtarzana u proroków myśl, że ci, którzy zamieszkają w Jerozolimie będą ludem Bożym (,,będą moim ludem, a Ja będę ich Bogiem"; 8, 8).

Prorok Joel każe zadąć w róg na Syjonie i wołać na górze świętej, bo nadchodzi dzień Jahwe ${ }^{38}(2,1)$, dzień ciemności i mroku $(2,2)$, dzień wielki i straszny $(3,4)$. W owym dniu przed sądem Jahwe staną narody (rozdzial 4). Z Syjonu zagrzmi Jahwe i podniesie głos swój z Jeruzalem $(4,16)$. Cały obraz na wydźwięk eschatologiczny zwłaszcza w porównaniu z podobnym obrazem u proroka Amosa, umieszczającego tron Boga Sẹdziego także na Syjonie ${ }^{39}$.

W obliczu sądu Bóg jest jednak dla swego ludu ucieczką i ostoją (4, 16). „Każdy, który wezwie imienia Jahwe, będzie zbawiony, bo na górze Syjon będzie wybawienie, jak przepowiedział Jahwe, i wśród ocalałych będą ai, których wezwał Jahwe" $(3,5)$. Oni będą na wieki zamieszkiwać Jerozolimę $(4,20)$, a Jahwe zamieszka na Syjonie $(4,21)$. Bardzo ważnym jest jeszcze stwierdzenie Joela, że społeczność Syjonu jest świętym zgromadzeniem $(2,16)$, uzyska ono zmiłowanie Jahwe, pałającego zazdrosną miłością $(2,18)$, ale musi pokutować. Prorok dwukrotnie wzywa do pokuty $(1,13-20 ; 2,15 \mathrm{nn})$.

U Trito-Izajasza rozszerzają się horyzonty w wizji Syjonu. Do niego Bóg przyprowadzi wszystkie narody garnące się do Jerozolimy (Iz 56, 7; 60, 3-9). Nad Jerozolimą rozbłyśnie chwała Boża $(60,1)$. Jerozolima bę-

${ }^{34}$ Por. W. Eichrodt, Theologie des AT, Goettingen ${ }^{5}$ 1957, t. 1, s. 56.

${ }_{35}$ Por. J. Schreiner, jw. (przyp. 3), s. 295; Th. C. Vriezen, Theologie des AT, Wageningen 1956, s. 63.

36 Por. Th. C. Vriezen, jw., s. 315.

37 Jako proroctwo Zachariasza przyjmujemy Za 1-8, drugą część Księgi Zachariasza $(9-14)$ przypisujemy Deutero-Zachariaszowi.

38 „Dzień Jahwe, Pański - w ST jest to dzień lub czas, kiedy Bóg dla dobra swojego ludu wkroczy w jego dzieje" BT², Słownik, s. 1422.

39 Por. E. Z a wiszewski, jw. (przyp. 20), s. 187. 
dzie „Miastem Jahwe i Syjonem Swiętego u Izraela” (60, 14). W niej nie będzie już krzywdy, spustoszenia i zagłady, lecz ocalenie, pokój i sprawiedliwość $(60,17 \mathrm{n})$. Jahwe będzie światłością wieczną miasta i jego ozdobą $(60,19)$. Cały lud Jerozolimy, z małej Reszty wyrosły w potężny naród $(60,22)$ będzie ludem sprawiedliwych $(60,21)$ i kapłanami Jahwe $(61,6)$, ludem świętym $(62,12)$. Sprawiedliwość Jerozolimy zabłyśnie jak pochodnia $(62,1)$. Przyjdzie do niej jej Zbawca niosąc nagrodę i zapłatę $(62,11)$. Apokaliptyczny obraz pomsty Boga potężnego w wybawieniu (63, 1-6) kończy omawianą tu wizję Syjonu u Trito-Izajasza.

$\mathrm{Na}$ końcu naszego przeglądu pism prorockich zatrzymamy się przy Deutro-Zachariaszu. Według jego apokaliptycznej wizji w epoce mesjańskiej Palestyna i Jerozolima jako centrum walki z nieprzyjacielem przejdą głębokie przemiany wewnętrzne a nawet geograficzne ${ }^{40}$, a Jerozolima zostanie wywyższona (Za 14) i będzie stolicą jedynego króla Jahwe (14, 9). Stanie się ona upajającą czarą $(12,2)$ i ciężkim głazem $(12,3)$ dla postronnych narodów, a dla oczyszczonego i wypróbowanego ludu Bożego $(13,9)$ wytryśnie w niej źródło dla obmycia grzechu i zmazy $(13,1)$. O ostatecznym zwycięstwie decyduje całkowite nawrócenie się do Jahwe i pokorna ufność pokładana $\mathrm{w}$ sprawiedliwości Jahwe ${ }^{41}$. Na Syjonie zapanuje radość, gdyż wkroczy do niego pokorny Król Pokoju (9, 9m).

\section{GEOWNE ELEMENTY TEOLOGICZNEGO OBRAZU SYJONU W STARYM} TESTAMENCIE

Przeprowadzona szczegółowo, choć nie wyczerpująco, analiza wypowiedzi Starego Testamentu o Syjonie pozwala nam na postawienie następującego wniosku:

Teologia Syjonu wyrosła $z$ faktów historycznych, interpretuje je teologicznie; wraz z uptywem czasu $i$ dokonywania się przemian historycznych teologia Syjonu ulega ewolucji, zachowujac jednak pewne stałe elementy.

Syjon i Jerozolima stały się przedmiotem zainteresowania hagiografów, bo tam Dawid założył swoją stolicę, tam umieszczono Arkę Przymierza, tam Salomon zbudował świątynię Jahwe. W ten sposób Syjon stał się centralnym punktem politycznego i religijnego życia Izraela. Izrael jednak był narodem wybranym przez Jahwe, dlatego właściwym królem Izraela był zawsze Jahwe. Stąd królestwo Dawida było królestwem teokratycznym, a poprzez króla z domu Dawida miał panować Jahwe. Syjon stał się stolicą Jahwe, miejscem Jego zamieszkania. Do tego samego

40 Por. J. Homerski, jw. (przyp. 19), s. 54.

41 Por. J. Ho merski. Księga Zachariasza, [w:] Księgi proroków mniejszych, praca zbiorowa, Pozmań 1968, t. 2, s. 425. 
wniosku doprowadziło sprowadzenie Arki - narzędzia zbawczej Bożej obecności, Jahwe zamieszkał na Syjonie także dlatego, że tu była Jego jedyna świątynia. Tak to teologiczna interpretacja faktów historycznych wytworzyła w świadomości Izraelitów przekonanie o Syjonie jako świętej górze Jahwe, którą sobie wybrał, umiłował, na której założył stolicę. Teologiczna interpretacja Syjonu przedstawiona powyżej odpowiada podanej przez Th. C. Vriezena pierwszej, wstępnej fazie starotestamentalnej eschatologii ${ }^{42}$. Główna obietnica, której spełnienia spodziewał się Izrael została osiągnięta w teokracji Dawidowej. Syjon jako stolica tej teokracji odnosi się do doczesnej historii, w której działa Bóg. Ma on także zabarwienie polityczne.

Stolica Jahwe jednak musiała być trwała. Tymczasem Izrael okazał się niewierny, a królestwo polityczne dalekie było od teokratycznego ideału. Prorocy więc zapowiadają inne uformowanie ludu Bożego, pojawia się idea Reszty Izraela, która jest wierna Bogu i przez Niego wybawiona od nadchodzącej kary. Izraelowi bowiem, jak i ludom ościennym grozi sąd Boży. Wtedy okaże się przegrana niewiernych, którzy poniosą karę, a wierna Reszta ocaleje. Wraz z ideą Reszty pojawia się idea mesjańska i myśl o zbawieniu w sensie moralnym. Wszystkie te idee ściśle związane są z Syjonem. Tak więc obraz Syjonu staje się bogatszy. Syjon bowiem to jakby ognisko soczewki skupiające w sobie całe oczekiwanie Izraela. Mesjanizm jest $\mathrm{w}$ tym okresie ściśle związany z dynastią Dawidową. To powiązanie mesjanizmu $\mathrm{z}$ domem Dawida wiąże go $\mathrm{z}$ Syjonem jako stolicą dynastii. Mesjasz zasiądzie na Syjonie, więc z Syjonu przyjdzie wybawienie, na Syjonie też Jahwe zgromadzi Resztę, bo Syjon to centralny punkt Izraela. Tak więc historyczne fakty $w$ teologicznej interpretacji proroków przyczyniają się do rozwoju wizji Syjonu. Rozważany obecnie etap rozwoju wizji Syjonu odpowiada protoeschatologii w sensie Vriezena. Obietnice odnoszące się do ostatecznej przyszłości dotyczą przemiany wewnętrznej $\mathrm{w}$ czasach mesjańskich. Ośrodkiem tej przemiany, tronem Mesjasza i miejscem zgromadzenia Reszty jest Syjon. On więc staje się rzeczywistością eschatologiczną, na razie $\mathrm{w}$ wymiarze protoeschatologicznym.

Następny etap rozwoju wizji Syjonu wywołany jest upadkiem państwa i niewolą. Był to wstrząs dla świadomości Izraelitów. Na niewzruszonym Syjonie leżą gruzy świątyni Jahwe, wieczna dynastia Dawida kończy panowanie w Jerozolimie. Jahwe nie może dopuścić, aby taki stan rzeczy trwał długo. Niebawem więc muszą zrealizować się eschatologiczne obiet-

${ }_{42} \mathrm{Tu}$ i w dalszym ciągu odwołuję się do przedstawionego przez Th. C. Vriezena podziału eschatologii Starego Testamentu. Vriezen podaje cztery fazy rozwoju myśli eschatologicznej w Starym Testamencie: preeschatologia, protoeschatologia, eschatologia realizująca się niebawem, eschatologia transcendentna. 
nice, ale już nie w dotychczasowej postaci. Syjon traci zupełnie sens historyczny i polityczny. Syjon to już rzeczywistość czysto eschatologiczna, fundament nowego porządku, który nadejdzie wnet. Przecież moc sił wrogich Bogu nie może trwać długo. Th. C. Vriezen nazywa ten etap eschatologicznego oczekiwania eschatologią realizującą się niebawem. Deutero-Izajasz widzi radosny powrót $\mathrm{z}$ niewoli na Syjon, Ezechiel zapowiada nowy kształt świątyni w Jerozolimie. O ile przed niewolą Syjon był związany z kontynuacją przymierza Synajskiego, Jahwe z Synaju przybył na Syjon, o tyle teraz wiąże się z przyszłym, nowym i wiecznym przymierzem, z ostatecznym zakrólowaniem Boga. Zbawienie wychodzące z Syjonu obejmie także pogan (Iz 49, 6n).

To eschatologiczne oczekiwanie Izraela i związana z nim ściśle wizja Syjonu ulegną dalszej ewolucji pod wpływem doświadczeń dziejowych. Izraelici wrócili na miejsce oznaczone w geografii mianem ,Jerozolima" i odbudowali świątynię na wzgórzu nazwanym „,Syjon”. Nie była to jednak Jerozolima i nie był to Syjon w tym sensie, w jakim terminów tych używali prorocy. Eschatologiczne treści wizji Syjonu zrealizują się zatem dopiero w związku z dniem Jahwe (Joel). Na końcu więc drogi rozwoju starotestamentalnej teologii Syjonu staje się on rzeczywistością transcendentnie eschatologiczną. Takiej rzeczywistości dotyczą wizje Syjonu Trito-Izajasza i Deutero-Zachariasza. Stary Testament zapowiadał, ale nie ujrzał realizacji prorockich wizji o Syjonie. Tej realizacji trzeba szukać dopiero w Nowym Testamencie.

Mimo wyraźnej ewolucji obrazu Syjonu w Starym Testamencie, teologia Syjonu zawiera pewne stałe elementy, które można odnaleźć na wszystkich etapach rozwoju. Te elementy postaramy się obecnie zebrać. Pierwszym stałym elementem teologii Syjonu jest omawiane przez nas poprzednio związanie Syjonu z eschatologicznym oczekiwaniem Izraela. Eschatologia Starego Testamentu ulegała ewolucji, z nią zmieniała się wizja Syjonu. Powiązanie istniało zawsze, co zostało już wyżej wykazane i chronologicznie prześledzone. Na podstawie przeglądu teologii Syjonu możemy stwierdzić, że następujące elementy wizji Syjonu w Starym Testamencie powtarzają się stale:

- Syjon jest wybranym przez Boga miejscem Jego przebywania;

- Syjon jest stolicą Jahwe silnie ugruntowaną i trwałą;

- Syjon jest związany z teokracją i mesjanizmem królewskim;

- z Syjonu przyjdzie zbawienie;

- na Syjonie rozbłyska chwała Jahwe;

- Syjon to miejsce zgromadzenia ludu Bożego, wśród którego mieszka jego Bóg,

- zgromadzenie przy Syjonie ma charakter kultyczny,

- Syjon wiąże się z sądem Bożym. 
Zajmiemy się jeszcze szerzej ostatnim z wymienionych aspektów Syjonu. Nie miejsce tu, aby rozwijać starotestamentalną teologię sądu Bożego, pewnych jednak uwag nie można pominąć, gdyż ten aspekt Syjonu przy przeglądzie tekstów Starego Testamentu mówiących o Syjonie narzuca się szczególnie dobitnie. Teksty bowiem o Syjonie w najbliższym lub niedalekim kontekście mają teksty o sądzie. Ten kontekst sądu Bożego towarzyszy wizji Syjonu, jak to podkreślaliśmy wielokrotnie. Jest w tym pewna prawidłowość, której w teologii Syjonu nie można pominąć. Tak więc teologia sądu Bożego splata się z teologią Syjonu. Syjon jest punktem centralnym, gdyż jest siedzibą Jahwe, który jest Bogiem wszystkich, bo Bogiem jedynym. Wszyscy więc wobec Jahwe muszą stanąć, a zatem wobec Syjonu, który jest Jego stolicą. Obecność Jahwe jest ambiwalentna, karze niewiernych, napełnia radością i dobrami wiernych. Rozwój tej podstawowej w teologii sądu Bożego idei śledziliśmy już wyżej i widzieliśmy jej związki z Syjonem od początku teologicznej interpretacji faktów leżących u podstaw teologii Syjonu. Sąd Boży w pierwszym rzędzie to rozdział niesprawiedliwych i sprawiedliwych. Dla pierwszych interwencja Boga to straszny i mroczny, pełen grozy i nieszczęść dzień Jahwe, dla drugich to radość z oczyszczenia i uczestnictwa w świętym zgromadzeniu. Sąd to rozrachunek z wrogami i królowanie Jahwe wśród swego ludu. Sąd Boży ma więc już w Starym Testamencie aspekt optymistyczny, ale Stary Testament podkreśla moment grozy i kary, ponieważ każdy za Psalmistą musiał powtarzać: „Uznaję bowiem moją nieprawość, a grzech mój jest zawsze przede mną" $(51,5)$ i każdy czuł to, co sformułował św. Paweł, że ,w Prawie nikt nie osiąga usprawiedliwienia przed Bogiem" (Ga 3, 11). W radosnej rzeczywistości sądu Bożego w pełni uczestniczyć będzie dopiero eschatologiczna Reszta, z którą Bóg zawrze nowe przymierze. Reszta ta na zawsze zamieszka na Syjonie.

\section{THEOLOGIA SIONIS IN VETERE TESTAMENTO}

S u m m a ri u m

Sion et Jerusalem in primis geographicae significationes sunt, sed Vetere in Testamento theologicum sensum accipiunt, qui in historica realitate fundatur et supra historicam functionem Davidici capitis ac montis Templi Salomonis spectat. Praeambula theologiae. Sionis e historia profluunt, nempe facta ista sunt: captio arcis in Sion a rege David, ingressus arcae foederis, fundatio potestatis regalis in stirpe Davidica in Jerusalem, aedificatio templi a Salomone perducta. Ad constituendam theologiam Sionis praesertim regnum Davidis et sanctuarium in Sion 
magni momenti sunt. Thronus regni David visibile signum dominationis Dei suo in populo est, templum vero locus habitationis Domini in medio hominum representat. Ergo Sion ut sedes regalis et mons templi regnum et habitationem Defi significat. Theologia Sionis humc aspectum evolvit.

Liber Psalmorum in expositione huius theologiae in primis enumerandus est. Sion est mons Dei et urbs Jahwe specialiter electa. Electıo Dei aeternam durabilitatem dat Sioni in quo gloria Dei habitat. Sion etiam locus divini iudicii constituitur. „Exurgit Deus, et dissipantur inimici eius; et fugiunt qui oderunt eum a facie eius. Sicut dissipatur fumus, tu dissipas; sicut fluit cera a facie ignis, sic pereunt peccatores a facie Dei. Et iusti laetentur et exultent in conspectu Dei, et delectantur in laetitia" (Ps 68, 2ss). Proinde Liber Psalmorum specialia cantica involvit quae altitudinem et valorem Sionis laudant ac laetitiam populi peregrinantis ad Sion exprimunt.

Prophetae Veteris Testamenti cum Sione venturae promissiones coniungunt. Sion eschatologicum regnum Dei et locum congregationis Reliqui significat.

Theologia Sionis Vetere in Testamento in decursu temporum evolutionem patitur huius in fine evolutionis in Novo Testamento vocabulum "Sion" synonymice pro Ecclesia utitur. 